\title{
Identification of Barriers to Financial Inclusion Among Youth
}

\author{
Amra Babajić ${ }^{1}$, Jasmina Okičić ${ }^{1}$, Meldina Kokorović Jukan ${ }^{1}$ \\ ${ }^{1}$ Faculty of Economics, University of Tuzla, Bosnia and Herzegovina \\ Correspondence: Amra Babajić, Faculty of Economics, University of Tuzla, Univerzitetska 8, 75000 Tuzla, \\ Bosnia and Herzegovina.
}

Received: April 30, 2018

doi:10.5539/ibr.v11n7p120
Accepted: May 29, $2018 \quad$ Online Published: June 15, 2018

URL: https://doi.org/10.5539/ibr.v11n7p120

\begin{abstract}
In recent years there is an increasing research attention on youth and their transition to adulthood. In that transition they have increasing demand for financial products and services. If they are not financial included it may leave long-lasting consequences for their future independence and stability.

The main goal of this research is to investigate and explain barriers to poor financial inclusion of youth in Federation of Bosnia and Herzegovina $(\mathrm{FBiH})$, and make some recommendations for increasing their financial inclusion, and indirectly for strengthening their social inclusion. Implications of this study suggest that the main reason for being unbanked is because someone else in the family already has an account, or because they do not have enough money to use services of financial institutions. The results have revealed statistically significant relation between need for financial services at a formal institution and having a bank account, category of students' financial knowledge and having a bank account, having a debit card and having a credit card. Research results can serve the economic and social policy makers in the FBiH in policy and strategy design.
\end{abstract}

Keywords: financial inclusion, measurement of financial knowledge, youth

\section{JEL Classification: I32, D14, C8}

\section{Introductory Considerations}

Although financial inclusion plays significant role in inclusive growth of every country, according to the World Bank around two billion people do not use formal financial services and more than $50 \%$ of adults in the poorest households are unbanked. Financial inclusion is defined as the process by which access to and the use of formal financial services are maximized, whilst minimizing unintended barriers, perceived as such by those individuals who do not take part in the formal financial system (Cámara \& Tuesta, 2014).

Financial exclusion refers to part of population that do not has or have poor access to financial products and services. Inadequately managing or uncontrolled finance can take individual into poverty or social exclusion. Young people are one of the most vulnerable groups. According to United Nations it is estimated that less than $5 \%$ of youth have a savings account as they face many barriers to access financial services. So, in this article we try to identify the most common barriers to financial inclusion, whose elimination would enable youth to realize their full economic potential. Broader financial inclusion, in general, lead to faster economic growth and higher rates of employment.

Since 2011, three-quarters of a billion people have gained access to financial services, and the number of young adults (age 15-24) holding an account at a formal institution increased from 37 to 46 percent (Child and Youth Finance International [CYFI], 2016). This data indicates big challenges for governments and international organizations. But, in the underdeveloped and developing countries the challenge is even greater. Latest Findex data (Financial Inclusion Data) for Bosnia and Herzegovina (BiH) show that just 53\% people ages over fifteen years have account in financial institution, which is far away from average of developed countries (94\%) and also far away from average from neighbor countries: Croatia 86\%, Serbia 83\% (World Bank Open Data, 2017). Having that in mind, in this research we try to investigate barriers to financial inclusion of youth and to give some useful recommendations.

Young people (ages between 15 and 24) in $\mathrm{BiH}$ are one of the most vulnerable group, mainly due to high youth unemployment rate (62.3\% according to Agency of statistics in 2015) and according to financial inclusion data. 
The main goal of this paper is to identify and explain reasons of poor financial inclusion of youth in the Federation of Bosnia and Herzegovina $(\mathrm{FBiH})$.

The central research hypothesis shall be as follows: difficult access to finances; low level of information; high price of financial products/services; too many documentary preconditions; physical distance of financial institutions and financial knowledge are contributing to lower level of financial inclusion of youth in Federation of Bosnia and Herzegovina.

The results of this study give useful information for government decision makers in the $\mathrm{FBiH}$ in the process of creation economic policies and strategies. In addition, first part refers to definitions, importance and barriers to financial inclusion and gives previous research of financial inclusion. Part two outlines data and methodology, while the third part provides analysis and discussion of the empirical results. At the end paper contains some conclusions and recommendations.

\section{Theoretical Background and Literature Review}

It is commonly argued that the economy as a whole benefits through financial inclusion (Mohan, 2006). Considering that young people make up a significant part of the population and are important for economic growth of each country, greater financial inclusion in this part of population is imperative. Adequate level of financial inclusion of youth brings benefits to the community and its economic growth, as well as for individuals.

Access to financial and social assets is a key contributing factor to help youth make their own economic decisions and escape poverty (United Nations, 2013). Access to formal financial services leads to higher financial capability, which positively affects economic and financial transitions to adulthood (Johnson \& Sherraden, 2007; Lusardi, Mitchell, \& Curto, 2010). Financial inclusion aims at drawing the "unbanked" population into the formal financial system so that they have the opportunity to access financial services ranging from savings, payments, and transfers to credit and insurance (Hannig \& Jansen, 2010).

European Union adopted youth strategy that acknowledges young people as both a most vulnerable group and a precious resource in an ageing Europe (European Commission, 2012). Given the importance of ensuring the financial inclusion of youth, the e-MFP Youth Financial Inclusion Action Group was established in 2010 with the objective of contributing to the growing body of experience in providing much-needed financial and complementary services to youth in developing countries (European Microfinance Platform, 2018).

Indicators of access barriers show a negative correlation with actual use of financial services confirming that they can exclude individuals from using bank services (Beck et al., 2007). Barriers of financial inclusion of youth can refer to existing regulation which (in some countries) disable young people (under 18 years or under the age of majority as prescribed by national law) to have an account, or it refers to general financial inclusion barriers with which all age groups meet.

And while obstacles and reasons vary between countries and regions, a number of common barriers emerge that generally represent a mix between supply-driven and demand-driven factors: Lack of financial understanding or information between providers and consumers; Gender and age discrimination; Poor people's low income and erratic cash flow; Geographic distances and high transaction costs for banks to operate in remote locations as well as high transport and opportunity costs for people to bank with formal financial institutions, etc. (Plan, Barclays, CARE, 2013). Kesavan (2015) discussed factors that are affecting access to financial services as psychological and cultural barriers, legal identity, income level, terms and conditions, procedural formalities, limited literacy, place of living, social security payments, occupation types and product attractiveness.

Rani (2015) developed a conceptual framework to analyses the impact of financial inclusion by investigating the availability of banking and financial services in rural areas. The author finds out that financial illiteracy, lack of awareness about the product, failure in reaching the poor, various regulations, financial literacy, income level, trust and non-availability of bank branches in rural areas are challenges of financial inclusion faced by banks.

Shankar (2013) summarizes the factors or barriers to financial inclusion as follows: The supply side factors include physical barriers, lack of suitable products, documentation barriers. On the demand side barriers as psychological, cultural, lack of financial literacy are regarded as important factors by the task force.

Demirguc-Kunt \& Klapper (2012) summarizes financial inclusion barriers as: physical, bureaucratic, and financial barriers (formal accounts too expensive). Most of recent research of financial inclusion levels around the world relies on the data from Global Findex database. So, in this research we adopted the most common reasons for being excluded (not having bank account) which is developed for the Global Findex Database. For this purpose we talk about next common reasons: religious reasons, lack of trust, cannot get an account, lack of necessary documentation, financial institutions too far away, accounts too expensive, family member already has 
an account, do not need an account, not enough money.

The Committee on Financial Inclusion (Chairman: C. Rangarajan) defines financial inclusion as the process of ensuring access to financial services and timely and adequate credit where needed by vulnerable groups such as weaker sections and low income groups at an affordable cost. Focus is on vulnerable and poor population, which also applies to young people considering their high unemployment rates. One of imperatives aiming to achieve the United Nations Sustainable Development Goals is developing entrepreneurial skills of youth. But, it is not possible to do it without their financial inclusiveness and literacy. Broader financial inclusion of youth is possible to achieve only by minimizing financial inclusion barriers.

Contrary to financial inclusion, financial exlusion is a reflection of social exclusion, as countries having low GDP per capita, relatively higher levels of income inequality, low rates of literacy, low urbanisation and poor connectivity seem to be less financially inclusive (Mandira \& Pais, 2008). High financial exclusion can lead to social exclusion, so why reduction of financial exclusion should be one of government priorities (Mitton, 2008).

The global push toward "financial inclusion" may be overtly about the penetration of financial instruments into untapped markets, but it is equally about social inclusion. Social assistance and wages, even for unskilled workers, are increasingly being channeled through banks and other formal payment mechanisms. Under these circumstances, lack of access to financial systems becomes an important axis of exclusion (World Bank, 2013).

In general the importance of financial inclusion can be revealed from the following (Shah \& Dubhashi, 2015):

1. It is a necessary condition for sustaining equitable growth.

2. It protects the poor people from the clutches of usurious moneylenders.

3. It will make possible for the governments to make payments under the social security schemes like National Rural Employment Guarantee Program (NREGA) through bank accounts of the beneficiaries, by Electronic transfers. This will minimize transaction costs including leakages.

4. It provides an avenue for bringing the savings of the poor into the formal financial intermediation system and channel them into investment.

5. The large number of low cost deposits will offer banks an opportunity to reduce their dependence on bulk deposits and help them to better manage both liquidity risks and asset liability mismatches.

Youth are a large part of the world population (1,5 billion), and make up the largest part of population in developing countries (20-60\% of the population) (The World Savings and Retail Banking Institute [WSBI], 2014), but unemployment rates for young people are higher than for adults (between two and three times higher). Youth have large financial needs, which means that in this period of life (commonly named transition) they have lot of aspirations (for example starting university, entering the labor market or starting a family) for which they need to be financial included. A big barrier to financial inclusion may leave them marginalized. So, it is very important do identify and minimize barriers to financial inclusion of youth, otherwise they cannot realize their economic potential, escape from poverty and it can lead to their social exclusion.

If it is possible to identify and minimize reasons of poor financial inclusion then it is possible to take steps to improve financial and social inclusion. Better financial power of individuals means greater social inclusion. On the other way, more competition between banks and financial inclusion are accelerating economic growth and work force demand, which means more inclusive growth. (Nenadović \& Golicin, 2015). Lack of access to financial services in combination of poor financial knowledge poses a substantial risk to the economic future and financial stability of youth.

This research is focused on identifying and analyzing barriers to poor financial inclusion of youth. Therefore, our theoretical concept is presented in Figure 1. 


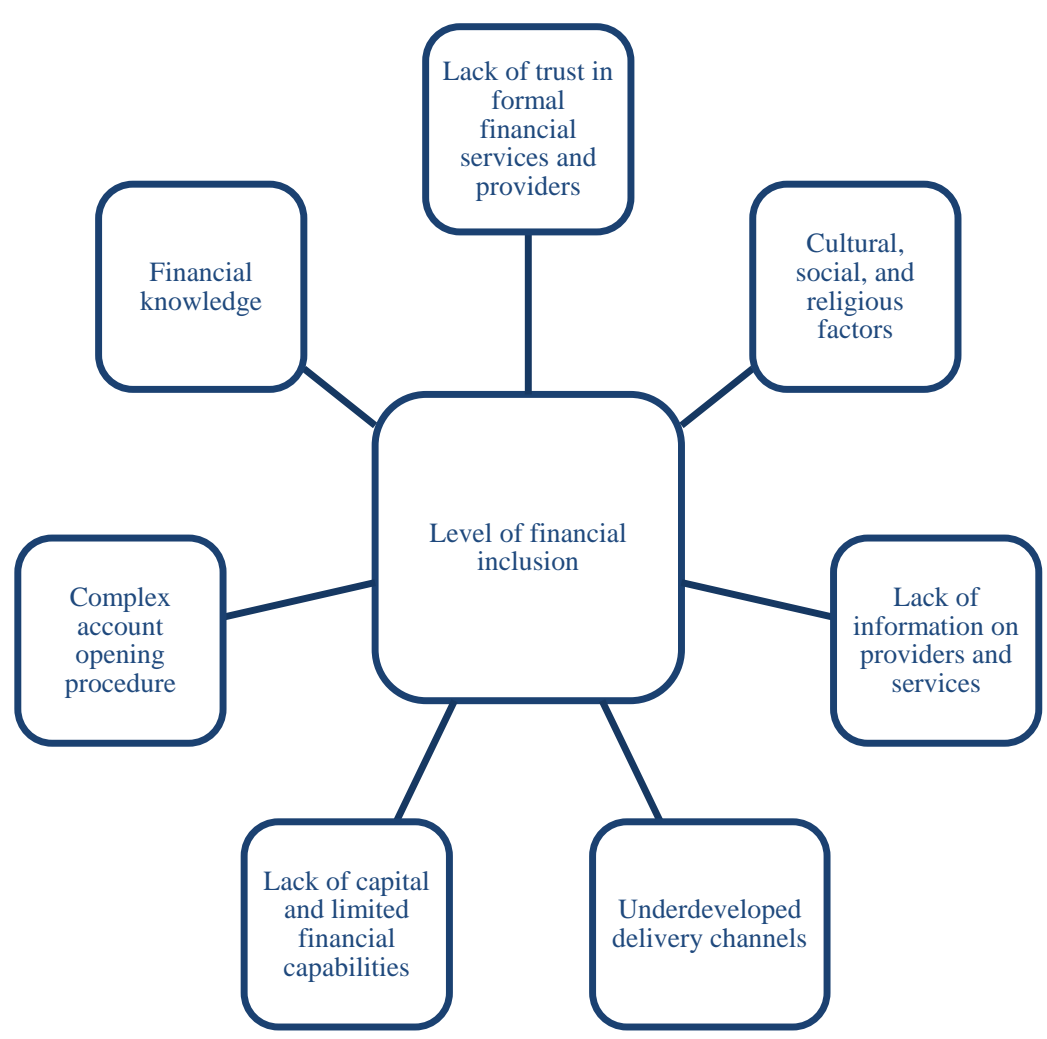

Figure 1. Theoretical concept

Source: Authors' own work

As discussed earlier our research is based on barriers to financial inclusion established for the Global Findex Database. In that way, in this research we focused on the following barriers:

- Lack of trust in formal financial services and providers. Confidence between clients and financial institutions is crucial, especially in less developed countries that faced with incidents in banks and trust is undermined. It is very difficult to financial relationship establish if clients perceive a wide gap between themselves and financial institutions.

- Cultural, social, and religious factors. Some people meet constraints in accessing and using financial services based on their religion, ethnicity, gender, age, or other socio-demographic factors. (e.g., minimum age to open a bank account, national identification, etc.).

- Lack of information on providers and services. Some potential clients don't have access to information about financial products and services, conditions and terms. This refers especially to inexperienced clients who don't appreciate the benefits of formal financial services and might not be aware of the different providers in the market.

- Underdeveloped delivery channels. Mobility constraints and weak infrastructure make travelling to the closest access point even more costly and difficult. So, financial institutions must provide their affiliations or ATMs in rural and less accessible places.

- Lack of capital and limited financial capabilities. This refers especially on vulnerable groups of population such as youth or woman in rural places who have no income, neither some other form of capital for collateral.

- Complex account opening procedure. In some cases banks requires a lot of documentation for opening an account, or this procedure takes a lot of time. (E.g. young people who don't have identity card and needs parent's signature for opening an account).

- Financial knowledge. Understanding key economic concepts, such as compound interest, savings etc. is crucial to informed financial decisions.

\section{Data and methodology}

As a representative of youth, in this study we used graduate students. We conducted primary research in which 
data are collected by the method of written tests using a structured questionnaire. Units of research are youth, students of the final years of all thirteen faculties of University of Tuzla: The Academy of Dramatic Arts, Faculty for Special Education and Rehabilitation, Faculty of Economics, Faculty of Electrical Engineering, Faculty of Physical Education and Sport, Faculty of Pharmacy, Faculty of Humanities and Social Sciences, Faculty of Mechanical Engineering, Faculty of Medicine, Faculty of Law, Faculty of Natural Sciences and Mathematics, Faculty of Mining, Geology and Civil Engineering, Faculty of Technology. It was a convenience sample unit consisted of total 205 graduate students from University of Tuzla. The participation in the study was voluntary and anonymous. Research was conducted during the second quarter of 2017. Table 1 gives overview of some basic characteristics of the sample.

Table 1. Basic sample characteristics

\begin{tabular}{|c|c|c|c|c|c|c|c|c|c|c|c|c|c|c|}
\hline \multirow{3}{*}{ Characteristics } & \multicolumn{12}{|c|}{ Fields of science } & & \\
\hline & \multicolumn{2}{|c|}{$\begin{array}{l}\text { Natural } \\
\text { sciences }\end{array}$} & \multicolumn{2}{|c|}{$\begin{array}{l}\text { Engineering } \\
\text { and } \\
\text { technology }\end{array}$} & \multicolumn{2}{|c|}{$\begin{array}{l}\text { Medical } \\
\text { and } \\
\text { Health } \\
\text { sciences }\end{array}$} & \multicolumn{2}{|c|}{$\begin{array}{c}\text { Agricultural } \\
\text { sciences }\end{array}$} & \multicolumn{2}{|c|}{$\begin{array}{c}\text { Social } \\
\text { sciences }\end{array}$} & \multicolumn{2}{|c|}{ Humanities } & \multicolumn{2}{|c|}{ Total } \\
\hline & $N$ & $\left(\%^{*}\right)$ & $n$ & $\left(\%^{*}\right)$ & $n$ & $\left(\%^{*}\right)$ & $n$ & $\left(\%^{*}\right)$ & $n$ & $\left(\%^{*}\right)$ & $n$ & $\left(\%^{*}\right)$ & $n$ & $\left(\%{ }^{*}\right)$ \\
\hline \multicolumn{15}{|l|}{ Sex } \\
\hline Male & 6 & 3.0 & 20 & 10.0 & 1 & 0.5 & N/A & N/A & 36 & 17.9 & 1 & 0.5 & 64 & 31.8 \\
\hline Female & 18 & 9.0 & 17 & 8.5 & 5 & 2.5 & N/A & N/A & 95 & 47.3 & 2 & 1.0 & 137 & 68.2 \\
\hline \multicolumn{15}{|l|}{ Place of residence } \\
\hline Urban & 14 & 6.9 & 26 & 12.9 & 3 & 1.5 & 0 & 0.0 & 88 & 43.6 & 2 & 1.0 & 133 & 65.8 \\
\hline Rural & 10 & 5.0 & 11 & 5.4 & 3 & 1.5 & 1 & 0.5 & 43 & 21.3 & 1 & 0.5 & 69 & 34.2 \\
\hline \multicolumn{15}{|l|}{ Education financing } \\
\hline $\begin{array}{l}\text { My parents finance } \\
\text { me }\end{array}$ & 15 & 7.4 & 29 & 14.2 & 4 & 2.0 & 0 & 0.0 & 92 & 45.1 & 2 & 1.0 & 142 & 69.6 \\
\hline I have scholarship & 3 & 1.5 & 1 & 0.5 & 0 & 0.0 & 0 & 0.0 & 2 & 1.0 & 0 & 0.0 & 6 & 2.9 \\
\hline I do casual jobs & 0 & 0.0 & 5 & 2.5 & 0 & 0.0 & 0 & 0.0 & 2 & 1.0 & 0 & 0.0 & 7 & 3.4 \\
\hline Other & 0 & 0.0 & 0 & 0.0 & 0 & 0.0 & 0 & 0.0 & 1 & 0.5 & 0 & 0.0 & 1 & 0.5 \\
\hline My parents finance & & & & & & & & & & & & & & \\
\hline $\begin{array}{l}\text { me and I have } \\
\text { scholarship }\end{array}$ & 5 & 2.5 & 2 & 1.0 & 1 & 0.5 & 1 & 0.5 & 18 & 8.8 & 1 & 0.5 & 28 & 13.7 \\
\hline $\begin{array}{l}\text { My parents finance } \\
\text { me and I do causal } \\
\text { jobs }\end{array}$ & 1 & 0.5 & 1 & 0.5 & 1 & 0.5 & 0 & 0.0 & 11 & 5.4 & 0 & 0.0 & 14 & 6.9 \\
\hline $\begin{array}{l}\text { I have scholarship } \\
\text { and I do causal jobs }\end{array}$ & 0 & 0.0 & 0 & 0.0 & 0 & 0.0 & 0 & 0.0 & 2 & 1.0 & 0 & 0.0 & 2 & 1.0 \\
\hline $\begin{array}{l}\text { My parents finance } \\
\text { me, I have } \\
\text { scholarship and I do } \\
\text { causal jobs }\end{array}$ & 0 & 0.0 & 0 & 0.0 & 0 & 0.0 & 0 & 0.0 & 4 & 2.0 & 0 & 0.0 & 4 & 2.0 \\
\hline \multicolumn{15}{|l|}{$\begin{array}{l}\text { Being a social } \\
\text { person-self } \\
\text { assessment }\end{array}$} \\
\hline Yes & 24 & 11.8 & 37 & 18.1 & 6 & 2.9 & 1 & 0.5 & 127 & 62.3 & 3 & 1.5 & 198 & 97.1 \\
\hline No & 0 & 0.0 & 1 & 0.5 & 0 & 0.0 & 0 & 0.0 & 5 & 2.5 & 0 & 0.0 & 6 & 2.9 \\
\hline
\end{tabular}

Note: $*$ of Total

Source: Authors' own work

The youngest graduate student from our sample is 22 years old, and the oldest is 31 year old. Average age is 23.73 years with standard deviation of 1.54 .

This research is focused on identifying barriers to poor financial inclusion of youth. In that way we use descriptive statistics as well as chi-square test. At first we tried to examine access to financial products and services and the use of financial products and services (which creates two dimensions of financial inclusion); and second to investigate reasons of poor financial inclusion of youth. As discussed earlier our research is based on barriers to financial inclusion established for the Global Findex Database.

\section{Results and Discussion}

When it comes to basic indicators of financial inclusion, it is evident that majority of youth in our sample have a bank account (77.1\%), and they have used it in the past 12 months (71.7\%). Overview of the relevant indicators of financial inclusion is presented in Table 2. 
Table 2. Basic indicators of financial inclusion of youth

\begin{tabular}{|c|c|c|c|}
\hline Item & Answer & Frequency & Percent \\
\hline \multirow[b]{2}{*}{ Do you have bank account? } & Yes & 158 & 77.1 \\
\hline & No & 46 & 22.4 \\
\hline \multirow{5}{*}{$\begin{array}{c}\text { Have you used your bank account in the } \\
\text { past } 12 \text { months? }\end{array}$} & No answer & 1 & 0.5 \\
\hline & Yes & 147 & 71.7 \\
\hline & No & 29 & 14.1 \\
\hline & No answer & 29 & 14.1 \\
\hline & Yes & 90 & 40.5 \\
\hline \multirow{2}{*}{ Do you have debit card? } & $\mathrm{No}$ & 80 & 35.5 \\
\hline & I do not know what debit card is & 16 & 7.8 \\
\hline \multirow{4}{*}{$\begin{array}{c}\text { Have you used debit card in the last } 12 \\
\text { months? }\end{array}$} & No answer & 19 & 9.3 \\
\hline & Yes & 84 & 41.0 \\
\hline & No & 38 & 18.5 \\
\hline & No answer & 83 & 40.5 \\
\hline \multirow{3}{*}{ Do you have credit card? } & Yes & 54 & 26.3 \\
\hline & No & 127 & 62.0 \\
\hline & I do not know what credit card is & 6 & 2.9 \\
\hline \multirow{4}{*}{$\begin{array}{c}\text { Have you used credit card in the last } 12 \\
\text { months? }\end{array}$} & No answer & 18 & 8.8 \\
\hline & Yes & 56 & 27.3 \\
\hline & No & 52 & 25.4 \\
\hline & No answer & 97 & 47.3 \\
\hline
\end{tabular}

Source: Authors' own work

As it can be seen, $22 \%$ of respondents are unbanked, but $77 \%$ of respondents have bank account which is better than results according to World Bank in 2014. in which 53\% of youth have bank account, but still far away from average of developed countries (94\%) and also far away from average from neighbour countries: Croatia 86\%, Serbia 83\% (World Bank Open Data, 2017).

Bank account didn't use $14 \%$ of respondents in the past 12 month, 35.5\% of respondents don't have debit card, but of those who has it $18.5 \%$ didn't use it in the last 12 months and even $7.8 \%$ of respondents doesn't know what is debit card. High $62 \%$ of respondents don't have credit card, and its usage is very poor. In this research we didn't explore how intensely accounts are used (high use, medium use, low use, or dormant), which would help us to investigate do young people fully benefit from financial inclusion in some further research.

Research showed some worrying data, for example only $22 \%$ respondents say When I need cash I go to bank, and only $2.9 \%$ declare I do not need cash, because I pay everything with card. Results of empirical research about reasons for being unbanked are given in the following figure.

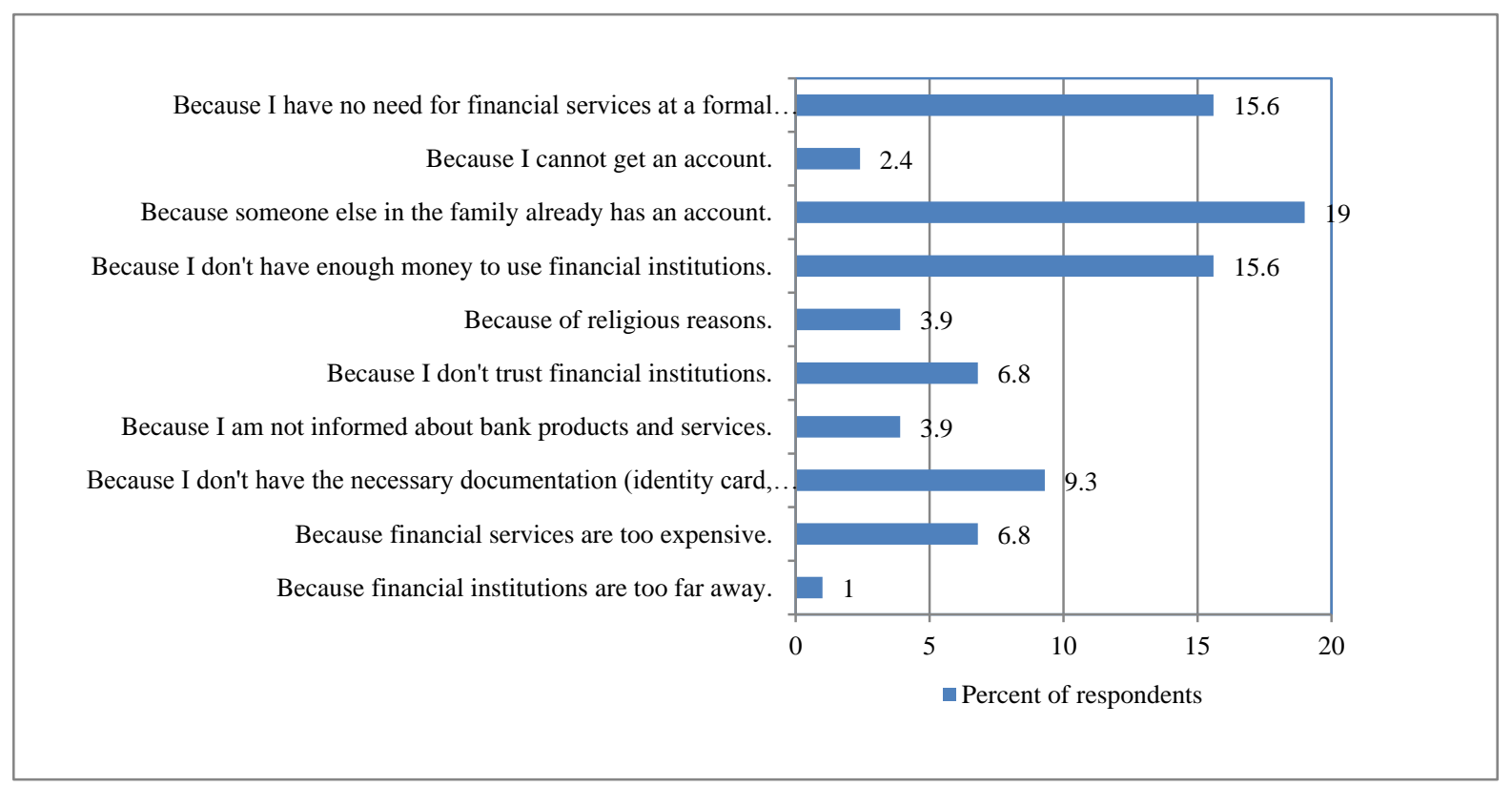

Figure 2. Identified barriers to financial inclusion of youth in Federation of Bosnia and Herzegovina Source: Authors' own work

A chi-square test of independence was performed to examine the relation between several dimension of financial 
inclusion, i.e. having a bank account, usage of bank account, having a debit card, having a credit card and savings. We used an alpha level of .05 for all statistical tests. We found statistically significant relation between a need for financial services at a formal institution and having a bank account, $\chi^{2}(1, N=204)=.030, p=.036$.

According to our theoretical concept, one of the assumed barriers to financial inclusion of youth is their financial knowledge.

In order to test this, we have calculated a financial knowledge score (FKS) by summarizing number of correct answers on the financial knowledge test $\left(F K_{i}, i=\overline{1,5}\right)$. The overview of the results is given in Table 3.

Table 3. Overview of the financial knowledge test

\begin{tabular}{|c|c|c|c|}
\hline Item & Answer & Frequency & Percent \\
\hline \multirow{3}{*}{ What is the difference between credit and debit cards? } & Correct & 59 & 28.8 \\
\hline & Wrong & 133 & 64.9 \\
\hline & No answer & 13 & 6.3 \\
\hline \multirow{4}{*}{$\begin{array}{l}\text { You lend your friend } 25 \text { BAM today. Tomorrow your friend gave you back } \\
25 \text { BAM. How much money have you earned in interest? }\end{array}$} & Correct & 165 & 80.5 \\
\hline & Wrong & 29 & 14.1 \\
\hline & No answer & 11 & 5.4 \\
\hline & Correct & 120 & 58.5 \\
\hline \multirow[t]{3}{*}{ Higher inflation leads to higher cost of living. } & Wrong & 80 & 39.0 \\
\hline & No answer & 5 & 2.4 \\
\hline & Correct & 96 & 46.8 \\
\hline \multirow[t]{3}{*}{ Higher risk leads to higher returns. } & Wrong & 104 & 50.7 \\
\hline & No answer & 5 & 2.4 \\
\hline & Correct & 87 & 42.4 \\
\hline \multirow[t]{2}{*}{ It is less likely to lose all of your money, if you save it in different places. } & Wrong & 113 & 55.1 \\
\hline & No answer & 5 & 2.4 \\
\hline
\end{tabular}

Source: Authors' own work

We have identified four categories of students, i.e. category of students with no financial knowledge ( 0 correct answers), solid (maximum 2 correct answers), average (maximum 4 correct answers) and excellent (maximum 5 correct answers) financial knowledge. Descriptive statistics for FKS is presented in Table 4.

Table 4. Descriptive statistics for FKS

\begin{tabular}{cccccc}
\hline Label & Variable & Minimum score & Maximum score & Mean score & Standard deviation \\
\hline FKS & Financial knowledge score & 0 & 5 & 2.57 & 1.43 \\
\hline
\end{tabular}

Source: Authors' own work

On average, students have financial knowledge that is below average. Following figure represents financial knowledge category in particular field of science.

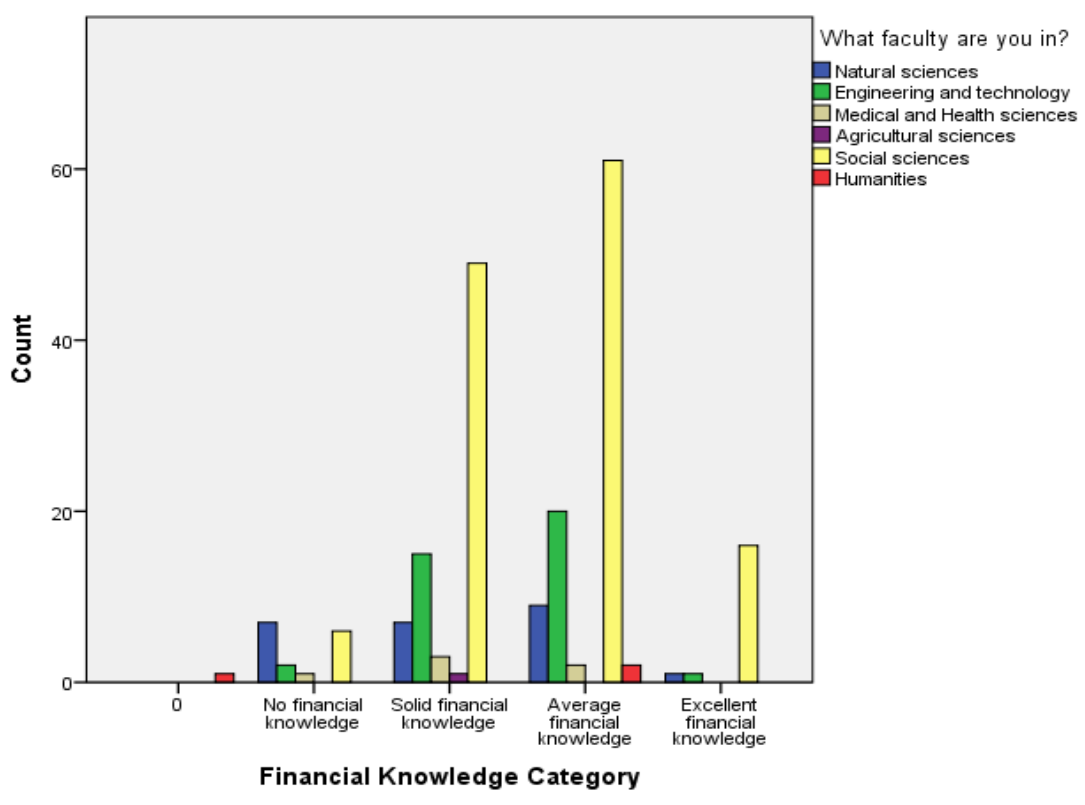

Figure 3. Financial knowledge category vs. field of science

Source: Authors' own work 
A chi-square test of independence was performed to examine the relation between categorise of students' financial knowledge and several dimensions of financial inclusion, i.e. having a bank account, usage of bank account, having a debit card, having a credit card and savings. We used an alpha level of .05 for all statistical tests.

We found statistically significant relation between:

- Category of students' financial knowledge and having a bank account, $\chi^{2}(4, N=204)=12.252, p$ $=.016$;

- Category of students' financial knowledge and having a debit card, $\chi^{2}(8, N=186)=38.117, p=.000$ and

- Category of students' financial knowledge and having a credit card, $\chi^{2}(8, N=187)=22.518, p=.004$.

In this research, we identified Because someone else in the family already has an account as a most frequently reason for being unbanked. Similar to Demirguc-Kunt \& Klapper, because someone else in the family already having an account were more commonly cited in middle- and high-income countries (Demirguc-Kunt \& Klapper, 2013). They choose to be passive in financial way, which can be ascribed to lack of information about financial products and services. Youth are often inexperienced clients who don't appreciate the benefits of formal financial services, so they don't feel need for financial services, and in the end they don't use their full financial potential. (19\% of respondents answered they are unbanked Because someone else in the family already has an account, and $15.6 \%$ said Because I have no need for financial services at a formal institution).

As discussed by Demirg-Kunt \& Klapper, the most common reason for not having a formal account, cited as the only reason by 30 percent of non-account holders, is lack of enough money to use one. This speaks to the fact that having a formal account is not costless in most parts of the world and that individuals with small or irregular income streams might view an account as an unnecessary expense, given the relatively high cost (Demirg-Kunt \& Klapper,, 2013). Also, 15.6\% of respondents in $\mathrm{FBiH}$ said Because I don't have enough money to use financial institutions. As we discussed earlier this refers especially on vulnerable groups of population and youth are one of them, they often don't have regular income or capital for collateral. Although they claimed that they don't have money for financial institutions, only $6.8 \%$ of respondents said that financial services are too expensive.

Next common reason for being unbanked is complex account opening procedure which in this case means that banks requires a lot of documentation for opening an account, (e.g. young people who don't have identity card and needs parents signature for opening an account).

As far as other reasons are concerned with the poor financial inclusion of youth it can be concluded that there is good level of confidence between them and financial institutions; they don't meet constraints in accessing and using financial services based on their religion, ethnicity, gender, age, or other socio-demographic factors; there is enough affiliations or ATMs which means there is no space barriers.

\section{Conclusion and Recommendations}

As discussed earlier financial exclusion can lead to social exclusion, so minimizing financial exclusion, or improving financial inclusion should be one of main goals of governments. It can be concluded that easy access to financial products and services in one of the key contributing factor to help youth make their own economic decisions, escape poverty and benefit their full potential. The more they are financially conscious and use the benefits of financial inclusion, have an open account, debit or credit card, they easier and faster get involved in various social groups, activities, forums, nongovernmental organizations, get faster employment, and ultimately it talks about how potential employers perceive their financial literacy and involvement. Only systematic evidence on barriers to the use of financial services allows policy makers to understand reasons for non-use and to prioritize and design policy interventions accordingly. In that way, this paper identifies that in Federation of Bosnia and Herzegovina youth are not adequate informed about benefits of formal financial services, they choose to be passive in financial way, they don't feel need for financial services, and in the end they don't use their full financial potential. Next common reason for being unbanked is lack of money and capital. In that respect government and financial institutions in this country, and general, must be more sound able for financial potential of youth by developing youth friendly banking products, which means there is need for products and services price-adjusted. Additionally they must find more accessible way to open an account for youth. Financial framework of each county, especially in Federation of Bosnia and Herzegovina must provide youth low-cost products by trained bank employees through innovative delivery channels.

It is necessary to take a lot of efforts to remove barriers and enhance the quality of financial and educational interventions. Those interventions should result in a widespread awareness of the importance of including youth 
in national financial inclusion strategies, and adding financial educations to school curricula.

\section{Acknowledgement}

This research is part of project Investigation of the Reasons of Poor Financial Inclusion among Youth Population in FBiH as Determinant of their Social Inclusion which is conducted under sponsorship of the Federal Ministry of Education and Science in 2016.

\section{References}

Beck, T., Demirguc-Kunt, A., \& Martinez Peria, M. (2007). Banking services for everyone? Barriers to bank access and use around the world. Policy Research Working Paper, 4079. Washington DC: World Bank.

Cámara, N., \& Tuesta, D. (2014). Measuring financial inclusion: A multidimensional index. BBVA Working Paper, 14(26), Madrid.

CYFI. (2016). Landscape series: Financial inclusion for children and youth. Retrieved from: https://issuu.com/childfinanceinternational/docs/cyfi-financial-inclusion-landscape [Accessed: January 2018].

Demirg-Kunt, A., \& Klapper, L. (2012). Measuring financial inclusion: The global findex database. World Bank Policy Research Working Paper, 6025.

Demirg-Kunt, A., \& Klapper, L. (2013). Measuring financial inclusion: Explaining variation in use of financial services across countries and within countries. Brookings papers on Economic Activity, Spring.

European Commission. (2012). Social inclusion of youth on the margins of society - Policy review of research results. Luxembourg: Publications Office of the European Union.

Government of India. (2008). Rangarajan committee report of the committee on financial inclusion. Retrieved from: https://www.sidbi.in/files/Rangarajan-Commitee-report-on-Financial-Inclusion.pdf [Accessed: January 2018].

Hannig, A., \& Jansen, S. (2010). Financial inclusion and financial stability: Current policy issues. ADBI Working Paper 259. Tokyo: Asian Development Bank Institute. Retrieved from: http://www.adbi.org/workingpaper/2010/12/21/4272.financial.inclusion.stability.policy.issues/ (Accessed: February 2018).

Johnson, E., \& Sherraden, M. S. (2007). From financial literacy to financial capability among youth. Journal of Sociology and Social Welfare, 34(3), 119-145, Western Michigan University.

Lusardi, A., Mitchell, O. S., \& Curto, V. (2010). Financial literacy among the young. Journal of Consumer Affairs, 44(2), 358-380. https://doi.org/10.1111/j.1745-6606.2010.01173.x

Mandira, S., \& Pais J. (2008). Financial inclusion and development: A cross country analysis. Retrieved from: http://icrier.org/pdf/Mandira\%20Sarma-Paper.pdf [Accessed: 12 April 2017].

Mitton, L. (2008). Financial inclusion in the UK: Review of policy and practice, Joseph Rowntree Foundation. Retrieved from: https://www.jrf.org.uk/sites/default/files/jrf/migrated/files/2234.pdf, [Accessed: September 2017].

Mohan, R. (2006). Economic growth, financial deepening and financial inclusion. Address at the Annual Bankers' Conference. Bank for International Settlements. Basel.

Nenadović, A., \& Golicin P. (2015). Finansijska inkluzija u Srbiji, Analiza stanja, prepreka, koristi i šansi. Team for social inclusion and poverty reduction, Serbia.

Plan, Barclays, CARE (2013). Banking on change: Breaking the barriers to financial inclusion. Retrieved from: https://www.home.barclays/content/dam/barclayspublic/docs/Citizenship/banking-on-change.pdf[Accessed: February 2018].

Rani, M. (2015). Conceptual framework to investigate the accessibility and impact of financial inclusion. International Journal of Science Technology and Management.

Shah, P., \& Dubhashi, M. (2015). Review paper on financial inclusion - The means of inclusive growth, Chanakya. International Journal of Business Research, 1(1), 37-48. Retrieved from: http://citeseerx.ist.psu.edu/viewdoc/download?doi=10.1.1.892.597\&rep=rep1\&type=pdf $\quad$ [Accessed: February 2018].

Shankar, S. (2013). Financial inclusion in India: Do microfinance institutions address access barriers? ACRN 
Journal of Entrepreneurship Perspectives, 2(1), 60-74. Retrieved from: https://pdfs.semanticscholar.org/4ad4/3e14111bd6a5ac1bd61949e16d3b0cdbd90e.pdf [Accessed: February $2018]$.

The World Bank. (2013). Inclusion matters: The foundation for shared prosperity, Washington D.C. Retrieved from:

https://openknowledge.worldbank.org/bitstream/handle/10986/16195/9781464800108.pdf?sequence=1\&is Allowed=y (Accesed: September 20, 2017).

United Nations. (2013). Financial Inclusion of Youth. Retrieved from: http://www.un.org/esa/socdev/documents/youth/fact-sheets/youth-financial-inclusion.pdf, [Accessed: February 2018].

World Bank. (2008). Finance for all? Policies and Ppitfalls in expanding access. Washington D.C.: World Bank.

WSBI. (2014). Financial inclusion for youth and young adults: Working with savings banks to double the number of savings accounts for the poor. Retrieved from: https://www.wsbi-esbg.org/SiteCollectionDocuments/WSBI_LEARNINGPAPER.pdf [Accessed: February $2018]$.

Kesavan, V. (2015). Financial inclusion in India - A road map towards growth of initiatives and achievements. IOSR Journal of Economics and Finance (IOSRJEF), 6, 26-39.

\section{Other internet resources:}

Agency of Statistics of Bosnia and Herzegovina. www.bhas.ba

European Microfinance Platform. http://www.e-mfp.eu

World Bank. www.worldbank.org

World Bank Open Data. https://data.worldbank.org/

\section{Copyrights}

Copyright for this article is retained by the author(s), with first publication rights granted to the journal.

This is an open-access article distributed under the terms and conditions of the Creative Commons Attribution license (http://creativecommons.org/licenses/by/4.0/). 